\title{
Communication of Emotions by Characters in a Flash Fiction (Based on Short Stories by Thomas Mann)
}

\author{
Tatiana V. Akasheva*, Nuria M. Rakhimova, and Tatiana V. Emets \\ Nosov Magnitogorsk State Technical University. Magnitogorsk. Russia.
}

\begin{abstract}
The paper is devoted to the issue of nonverbal explication of emotions in literary texts of a flash fiction. Nonverbal means of communication are studied in several directions. There are works reflecting this problem from the perspective of semiotics, linguistics, sociolinguistics and psycholinguistics. A number of scientists is engaged in lexical description of paralinguisms. The study of linguostylistic problems of paralinguisms in literary works presents a special interest. The appeal to this problem is explained by the fact that adequate interpretation of a literary text is impossible without the corresponding reader's understanding of nonverbal means of emotional expression since this requires nontrivial intellectual operations and a certain breadth of knowledge. The study is based on the analysis of three short stories by a famous German writer Thomas Mann: Der kleine Herr Friedemann (1898), Tobias Mindernickel (1898) and Tristan (1902). The rationale of the study is caused by the immaturity of this subject in German. The novelty is defined by the study of paralinguistic units in literary texts of T. Mann. The purpose of the paper is to describe nonverbal means and to define their functional yield in a literary text. To achieve this purpose, the paper deals with continuous sampling methods, contextual analysis and interpretation. The study showed that Thomas Mann uses paralinguisms to describe the main characters generally applying characterizing, evaluation, text-forming and forecast functions. Paralinguisms ensure text cohesion, integrity of its perception and are always aimed to implement the author's plan and create the fictitious world of a literary work and consequently, contribute to the expression of an idea and a subject. The materials of the given paper may be used in theoretical courses of German lexicology, stylistics and in practical classes on literary text interpretation.
\end{abstract}

\section{Introduction}

It is commonly known that nonverbal means of communication represent means of interaction between people without the use of words, where the communication of information is ensured through images, intonations, gestures, body language, and pantomimicry. Hence, paralinguisms are considered the semantic and emotional features of speech.

Unlike speech, nonverbal behavior is not much controlled, therefore it can be considered more informative as it displays authentic feelings and natural reactions. Paralinguisms bring additional value and are often used by writers to create the literary text. The authors of literary works following the letter of the law strive towards implicit rather than explicit description of heroes' emotions thus forcing the reader to experience a particular situation.

The appeal to nonverbal explication of emotions in a literary text acquires special relevance in foreign language teaching since nonverbal means of emotional expression are not always paid enough attention while teaching foreign languages. At present, when the higher school is facing an urgent task to train students focused on culture, mentality, and psychology of people of a studied language, such aspects as nonverbal communication cannot be neglected. It also defines the practical importance of the given study, which results are obtained through the analysis of a text in a source language and may be used in theoretical courses in lexicology, stylistics and in practical classes on the German literary text interpretation, namely during the study of classic German literature by T. Mann. The works devoted to this writer constitute a separate field of Germanic studies (Th. Mann-Forschung), which is now being actively developed.

The purpose of this paper is to identify contexts in the short stories by T. Mann, which include paralinguisms, and to describe the functional yield of these means in artistic discourse.

\section{Literature review}

Several directions have already been highlighted in the study of nonverbal means of communication. This study covers different aspects, including semiotics, linguistics (linguocentric aspect), sociolinguistics and 
psycholinguistics. The domestic study of paralinguistics within semiotics is outlined in different works by T.M. Nikolaeva [1-4], which consider the difference between conscious and unconscious use of paralinguisms, as well as classification of nonverbal functions in speech structure [1]. A. Wierzbicka [5] and G.E. Kreydlin [6] describe the fundamentals of nonverbal semiotics in its relation to linguistics. Similar ideas were mentioned in the study of typology of emotive signs by B. Volek [8].

The problem of nonverbal communication in psycholinguistics and psychology was raised in the monograph by I.S. Panova-Yabloshnikova, who analyzed features of recognizing nonverbal components of communication depending on the structure of intelligence [7] and in the work by V.P. Morozov [8] devoted to art and science of nonverbal communication. Paralinguisms are also considered as structure-forming components of speech in works of such famous linguists as R. Barthes [9], N.I. Zhinkin [10,11], E.A. Zemskaya, M.V. Kitaygorodskaya, E.N. Shiryaev [12]. R. Jacobson [13], C. Blanche-Benveniste and C. Jeanjean [14], A. Sauvageot $[15,16]$, etc.

V.B. Beglova [17], V.G. Khlystova [18], E.A. Anisimova [19], V.V. Bogdanov [20], E.L. Korlykhanova [21], G.V. Bayeva [22], etc. studied linguistic and pragmatical aspects. S.A. Grigorieva, N.V. Grigoriev and G.E. Kreydlin [23] attempted to compile a dictionary description of paralinguisms.

The paper especially considers linguostylistic interpretation of paralinguisms studied in works (E.A. Zueva [24], Yu.V. Ivanova [25], E.Ya. Kedrova [26], N.B. Nakashidze [27], O.G. Shashkina [28], K.D. Danow [29]), including based on the materials of the German language by V.I. Adanakova [30] and I.A. Golovanova [31].

\section{Methodology}

The methodological framework of the analysis includes systemic-functional analysis of linguistic units followed by the appeal to certain methods of psycholinguistics, nonverbal semiotics, functional stylistics, literary text interpretation. The methodology of the study is based on works by Barthes R., Wierzbicka A., Zemskaya E.A., Kedrovaya E.Ya., Kreydlin G.E., Jacobson R., etc.

The study is carried out using the empirical material obtained through continuous sampling and inductive methods: from observations of specific language material to generalization of obtained results. The main method is systemic-functional method, which includes the study of linguistic units in their system relations and taking into account their functionality. Besides, the descriptive method, the method of contextual analysis, analysis and statistical method were used.

\section{Results and discussion}

The study was based on the analysis of three most famous short stories by T. Mann included in the German literature course. The short stories by such a shrewd judge of character as Thomas Mann are ambiguous, they are imbued with high philosophical value and present an enormous interest from the general literary perspective. Since a person with his worries and doubts is always in the center of his short stories, the definition of emotions forms an integral part of these literary works.

The short story by Thomas Mann Der kleine Herr Friedemann $^{l}$ (1898) narrates about a small hunchback Friedemann, who at once felt the impossibility of life in this world. Life, which he was able to create and which he loved a lot (playing a violin, reading, visiting concerts, walking in a suburban garden), is suddenly destroyed when he falls in love with Gerda von Rinnlingen, a beautiful but willful and eccentric person. The love does not bring the hero any happiness. Throughout the short story the author shows the inwardness of the hero, his despair by describing his appearance and behavior. The authors of this paper selected 14 contexts including paralinguisms. The most frequently met descriptions in this short story are the descriptions of the face and head posture. Paralinguism Kopf and the description of the head posture occur 7 times in the text and are considered dominating: sein Kopf saß tiefer als je zwischen den Schultern. The repetition of posture sein Kopf saß tiefer als je zwischen den Schultern makes formal and semantic structure of a text, expresses implicit meaning and implements a textforming function.

The face is expectedly the most important sign of nonverbal communication: Herr Friedemann war bleich, viel bleicher als gewöhnlich, und unter dem glattgescheitelten braunen Haar standen kleine Tropfen auf seiner Stirn ${ }^{2}$. The attention to such details as gradually appearing pallor, heat drops seen on a forehead helps the author to implicitly transfer the state of mind of the hero, his fear and shyness when facing a new feeling. Sometimes only one part of the face is described, for example, a nose: Als der kleine Herr Friedemann ... seine Loge ... betrat, zuckte er in der Tür zurück, wobei er eine Bewegung mit der Hand nach der Stirn machte und seine Nasenflügel sich einen Augenblick krampfhaft öffneten ${ }^{3}$. The swelling wings of a nose is a sign of nervousness experienced by the main character before meeting a woman with whom he is passionately in love. $\mathrm{He}$ is waiting and is afraid of this meeting. The shock which is also felt by the hero is transmitted through the description of the shivering hands: seine Hände zitterten, und ein scharfer, drängender Schmerz stieg ihm aus der Brust den Hals hinauft. The hero constantly feels fear before the beloved one, therefore every time when she looks at him, he hangs the head down: Sein Kopf saß tiefer als je zwischen den Schultern, seine Hände zitterten, und ein scharfer, drängender Schmerz stieg ihm aus der Brust den Hals hinauf $f^{5}$. The head sank into shoulders expresses depression, thereby the author tries to transmit the depth of sufferings of the main character.

${ }^{1}$ Henceforward: Mann Thomas. Der Tod in Venedig. Erzählungen. 1. Auflage, Aufbau-Verlag Berlin und Weimer, 1980.411 s.

${ }^{2}$ Mann T. 1980 . pp. 12

${ }^{3}$ Ibid., pp. 12

${ }^{4}$ Ibid., pp. 13

5 Ibid., pp. 17 
In the following example the description of the head movement expresses the whole range of emotions: embarrassment, confusion: Sein Gesicht ward glühend rot, und ohne zu wissen, wohin er sich wenden sollte, völlig ratlos und außer sich, ließ er seinen Kopf ganz zwischen die Schultern sinken und blickte fassungslos auf den Teppich nieder ${ }^{6}$. The hero is unsociable, he wants to hide from everyone, which is shown by the description of the hung head: Jemand GR üßte ihn, aber er sah es nicht; er hielt den Kopf tiefgesenkt, und seine hohe, spitze Brust zitterte, so schwer atmete er ${ }^{7}$. The above examples illustrate the use of the characterizing function.

Throughout the short story T. Mann forces the reader to evaluate the degree of dissimilarity of heroes, using a certain 'paralinguistic antithesis': Sie setzte sich nahe bei ihm, legte die Arme auf die Seitenlehnen des Sessels und lehnte sich zurück. Er saß vorgebeugt und hielt den Hut zwischen den Knien ${ }^{8}$. In this fragment a free and relaxed posture of madam von Rinlingen is opposed to a tensed posture of mister Friedemann: she legte die Arme auf die Seitenlehnen des Sessels; he hielt den Hut zwischen den Knien; she lehnte sich zurück, and he saß vorgebeugt. Paralinguistic parallels in the description of heroes indicate how difficult it is for mister Friedemann to communicate with this woman. The author exposes markers and forces the reader to evaluate the nature of their relationship independently. Thus, within this context paralinguisms implement evaluation and textforming functions.

Two other short stories Tristan (1902) (11 contexts) and Tobias Mindernickel (1898) (4 contexts), analyzed by the authors, also show paralinguisms performing, first of all, the characterizing function though the description of other parts of the body are involved.

The main character of the short story Tristan Detlev Spinell strives for perfection, and the author constantly emphasizes his pretentiousness and estheticism: Da wies er ihr stumm das Titelblatt. Er war ganz bleich, ließ das Buch sinken und sah sie mit zitternden Lippen $a n^{9}$. The pallor of the face and the shivering lips apparently transmit the agitation of the hero. However, other movements (manipulations with a book) point out that the nervousness is either strummed or exaggerated. The reader understands that the hero is flabby and diffident by observing the change of his emotional state within a few seconds: self-confidence turns into confusion, nervousness into fear. This is shown by the description of voluntary and involuntary movements of hands: Sonderbarerweise lächelte Herr Spinell; er lächelte zuvorkommend, ein wenig verwirrt und halb entschuldigend, führte die Hände zum Kopf, als besänne er sich ${ }^{10}$.

At the beginning of the short story Tobias Mindernickel the reader sees a person with a rickety walk: Er selbst aber geht, ohne sich zu wehren und scheu um sich blickend mit hochgezogenen Schultern

\footnotetext{
6 Ibid., pp. 22

Ibid., pp. 25

Ibid., pp. 56

${ }^{9}$ Henceforward: Mann T. 1989. pp. 63

${ }^{10}$ Ibid., pp. 66
}

und vorgestrecktem Kopfe davon, wie ein Mensch, der ohne Schirm durch einen Platzregen eilt ... ${ }^{11}$ The walk of the hero sharply changes after he helps a child: $E r$ schritt fest und aufrecht, und seine Brust atmete tief unter dem engen Gehrock; seine Auge hatten sich vergrößert, sie hatten Glanz erhalten und fassten mit Sicherheit Menschen und Dinge, während um seinen Mund ein Zug von schmerzlichem Glücke lagl2. This case also shows the characterizing function. The description of details of nonverbal behavior allows the author giving compressed but concise characteristic of heroes.

The short story Tobias Mindernickel is interesting in respect of identifying the forecast function of nonverbal means. The lonely person experiences pathetic tenderness only to a puppy, whom he is attached to and for which he cares when the puppy is ill. But when the puppy recovers, Tobias kills him in a rush of rage. The description of eyes reflecting human feelings periodically appear along the plot: Er schritt fest und aufrecht, und seine Brust atmete tief unter dem engen Gehrock; seine Augen hatten sich vergr ößert, sie hatten Glanz erhalten und fassten mit Sicherheit Menschen und Dinge, während um seinen Mund ein Zug von schmerzlichem Glücke $\operatorname{lag}^{13}$. The light in the eyes demonstrates that the pathetic hero suddenly finds confidence and belief in own power over a weaker creature. The author concentrates on the description of eye expression of the hero: Tobias Mindernickel stand mit am Leib eher unter hängenden Armen ein wenig vorgebeugt, seine Lippen waren zusammengepresst und seine Augäpfel zitterten unheimlich in ihren Höhlen ${ }^{14}$. The reader does not know yet what will happen, but the resolute look of the main character anticipates further development of a plot.

This problem, undoubtedly, presents a great interest from the point of view of the cognitive approach, which will allow revealing linguo-cognitive explication methods of transmitting the emotions.

\section{Conclusions}

Using nonverbal means in his short stories Thomas Mann communicates the most delicate sides of human spiritual life, which requires a particular perception of his works. The task of the reader is to adequately interpret the message of the author, which is impossible without the corresponding understanding of the value of nonverbal means of emotional expression, "this process requires nontrivial intellectual operations, a certain breadth of knowledge and an ability to remember the necessary things at the right time" [32, p. 8]. The task of modern education is to teach this [33].

The analyzed set of paralinguisms (29 contexts) allows concluding that they are aimed at the explication of emotions and transfer of emotional state of characters. In the literary text nonverbal means of emotional

\footnotetext{
11 Ibid., pp. 30

${ }^{12}$ Ibid., pp. 31

${ }^{13}$ Mann Thomas. Tobias Mindernickel. pp. 33

${ }^{14}$ Ibid., pp. 36
} 
expression perform characterizing, evaluation, textforming and forecast functions. They are included in the narration along with speech characteristics of heroes and play one of the key roles in the formation of a plotline, a subject and an idea of the text. Therefore, paralinguisms contribute to the expression of author's intension and foster the integrity of the literary masterpiece.

\section{References}

1. T.M. Nikolaeva, Nonverbal means of human communication and their place in teaching language. Role and place of country studies in teaching Russian as a foreign language (M.: Publishing House of Moscow State University, 1969)

2. T.M. Nikolaeva, From sound to text (M.: Languages of the Russian culture, 2000)

3. T.M. Nikolaeva, B.A. Uspensky, Linguistics and paralinguistics. Linguistic study on general and Slavic typology (M.: Nauka, 1966)

4. Yu.V. Nikolaeva, Issues of linguistics 4, 48-67 (2004)

5. A. Wierzbicka, Emotions across languages and cultures: Diversity and universals (Paris: Cambrige University Press, 1999)

6. E. Kreydlin, Ecology of language and communicative practice 2, 100-120 (2014)

7. I.S. Panova-Yabloshnikova, Nonverbal components of communication: link between features of recognition and structure of intelligence: monograph ( $\mathrm{SPb}$.: Publishing House of Saint-Petersburg State University, 2003)

8. V.P. Morozov, Art and science of communication: nonverbal communication (M.: Institute of Psychology, RAS. 1998)

9. R. Barthes, Writing Degree Zero (Yekaterinburg: Business book, 2001)

10. N.I. Zhinkin, Speech as an information conductor (M.: Nauka, 1982)

11. N.I. Zhinkin, Language. Speech. (M.: Labirint Publishing House, 1998)

12. E.A. Zemskaya, Russian informal conversation. General questions. Word formation. Syntax (M.: Nauka, 1981)

13. R. Jacobson, Language and unconscious: (works of different years) (M.: Gnosis, 1996)

14. C. Blanche-Benveniste, C. Jeanjean, Le Français parlé: transcription et édition Texte (Paris: Didier, 1987)

15. A. Sauvageot, Analyse du français parlé (Paris: Hachette, 1972)

16. A. Sauvageot, Français écrit, français parlé (Paris: Larousse, 1962)

17. V.B. Beglova, Lexicon of kinesics (based on materials of the modern English language): Cand. Sci. (Phil.) Dissertation (M. 1996)
18. V.G. Khlystova, Functional-structural and semantic features of kinematic set phrases reflecting communicative aspect of kinesics (based on the English language): Cand. Sci. (Phil.) Dissertation (Nizhny Novgorod, 2005)

19. E.E. Anisimova, Creolized texts - texts of the $21^{\text {st }}$ century: Interaction of verbal and paralinguistic phenomena in a text: study manual on text interpretation (Voronezh: CChPH, 1999)

20. V.V. Bogdanov, Functions of verbal and nonverbal components in speech communication. Language communication: Units and regulatives: interuniversity collection of scientific articles (Kalinin: Publishing House of Kalinin State University, 1987)

21. E.L. Korlykhanova, Interaction of prosodic and kinesic means in emotional expression of joy, anger, surprise in a scenic speech (based on English language): Cand. Sci. (Phil.) Dissertation (M, 2000)

22. G.V. Bayeva, Semantic-pragmatic features of verbal and nonverbal language within an advertising discourse: extended abstract of Cand. Sci. (Phil.) Dissertation (Tambov, 2000)

23. S.A. Grigoryeva, N.V. Grigoriev, G.E. Kreydlin, Dictionary of Russian sign language (M.: Vienna, 2001)

24. E.A. Zueva, Verbalization of paralinguistic acts in a literary text of modern German literature: extended abstract of Cand. Sci. (Phil.) Dissertation (Belgorod, 2005)

25. Yu.V. Ivanova, Paralinguistic elements of a literary text: based on the French prose of the $20^{\text {th }}-21^{\text {st }}$ centuries: Cand. Sci. (Phil.) Dissertation (Smolensk, 2009)

26. E.Ya. Kedrova, Verbal features of gestures of characters during direct speech in a literary text: based on the prose by A.P. Chekhov: Cand. Sci. (Phil.) Dissertation (Rostov-on-Don, 1980)

27. N.V. Nakashidze, Kinesics and its verbal expression in the description of characters of a fiction (based on Anglo-American literary prose of the $20^{\text {th }}$ century): extended abstract of Cand. Sci. (Phil.) Dissertation (M. 1981)

28. O.G. Shashkina, Role of a speech voice and kinesic means in national and cultural specifics of emotional reaction (based on fiction books): extended abstract of Cand. Sci. (Phil.) Dissertation (M. 2006)

29. K.D. Danow, Russian literature 8, 41-75 (1980)

30. V.I. Adanakova, Paralinguistics as an assessment indicator in a literary text. Stylistic analysis of a literary text (Smolensk: Publishing house of Smolensk State University, 1988)

31. I.A. Golovanova, Bulletin of Novosibirsk State University. Series: History, philology 5(2), 86-95 (2006) 
32. T.V. Akasheva, S.A Pesina., N.M. Rakhimova, E.V. Zemlyanukhina, Issues of cognitive linguistics 2(47), 5-10 (2016)

33. T.F. Orekhova, T.V. Kruzhilina, Humanitarian and pedagogical research 1(1), 37-44 (2017)

34. B.A. Volek, Language and emotions: Collection of scientific articles (VSPU. Volgograd: Peremena, 1995) 